\title{
A life well lived: A tribute to Steve Savage
}

\author{
Pat Rogan ${ }^{\mathrm{a}, *}$ and J.P. Sandy ${ }^{\mathrm{b}}$ \\ a Indiana University School of Education, Indianapolis, IN, USA \\ ${ }^{\mathrm{b}}$ Easter Seals Crossroads, Indianapolis, IN, USA
}

Accepted 4 March 2015

\begin{abstract}
Steve Savage, who passed away recently, was a trainer, mentor, advocate, and leader in the disability field. This tribute highlights his professional accomplishments as a pioneer and champion for the rights of citizens with disabilities, as well as his personal zest for life.
\end{abstract}

Keywords: Steve Savage, transition, supported employment, organizational change, APSE

The world lost a very special human being when Steve Savage died unexpectedly from a heart attack on February 12, 2015 at the age of 63. Those who knew and loved Steve gathered in Indianapolis on March 7, 2015 for a memorial service and celebration of his life. Through laughter and tears, stories of Steve's adventures, passion for life, advocacy on behalf of individuals with disabilities, and sense of humor were shared.

Steve earned his bachelors and Masters degrees in education from Indiana University, after which he worked as a teacher with First Steps in South Bend, Indiana. He moved to Columbus, Indiana and worked in the industrial program at Developmental Services, Inc. (DSI) before moving to employment services and developing their supported employment option. Steve left DSI to travel in Europe for four months. Upon his return he did private consulting work for about 8 months and then took a job with the Indiana Institute on Disability and Community, working on a statewide systems change grant on supported employment and a transition systems change grant. Steve then moved to New Mexico and worked as a case manager for about a year. When he returned to Indiana he assumed the role of Employment Services Director at Gateway Services and led their initiative to close their sheltered workshop.

\footnotetext{
*Address for correspondence: Pat Rogan, Ph.D., Executive Associate Dean, Indiana University School of Education, 902 West New York Street, Indianapolis, IN 46202-5155, USA. Tel.: +1 317274 6862; E-mail: progan@iupui.edu.
}

He left Gateway to start his own consulting business, Sandy Savage Associates Inc., with Patrick Sandy. Steve took the lead with many exciting initiatives, including a statewide Business Advisory Council initiative. He also worked closely with the Indianapolis Public Schools and with Pat Rogan at Indiana University, Indianapolis to promote transition and employment services, including Project Search and the SITE program. He recently took the CEO position with the Arc of Greater Boone County. For the past 25 years Steve served as a lead trainer/owner of the Indiana Supported Employment Training Team (ISETT) and trained thousands of Employment Training Specialists. At the national level, Steve served on the APSE Board of Directors and as a consultant for Griffin Hammis \& Associates.

Trainer, mentor, pioneer, leader. Steve had a knack for moving people forward with a combination of diplomacy, wit, charm, and sheer will. He 'walked the walk' as a strong advocate for people with disabilities throughout his career - always staying 'in the trenches', always walking with people through their life journeys, and always advancing exemplary practices in the areas of transition, employment and organizational change. He was a true champion whose ongoing work at the local, state, and national levels helped to shape our field and impacted untold lives in positive ways. He challenged people to think differently about how to provide services. It is this legacy that led national APSE to recognize him with the first David Hammis award. 
Many of us strive to find balance in our lives, but fail miserably. Steve Savage showed us what working hard and playing hard look like. He understood that family and friends are most important in life and he made them his first priority. His wife, Deb, was the love of his life and he was a devoted father to their daughter, Amber. Steve trekked near and far to visit his family and many friends, always enjoying new adventures and making the journey as fun as the destination. One of his favorite places was New Mexico, as he was drawn to the spiritual customs of the American Indian and their value of "we are all responsible for the whole tribe." He loved baseball, music, nipping Irish whiskey, and his BMW motorcycle.

We had the pleasure of knowing and working with Steve for decades. He was a great 'partner in crime' who laced humor with hard work and a big, loving heart with his Irish fire. His was the epitome of a life well lived and we are better people for knowing him. His warm and humble spirit will live on in our hearts. 